\title{
Humoral immune response of European eel Anguilla anguilla to a major antigen in Anguillicola crassus (Nematoda)
}

\author{
K. Buchmann ${ }^{1}$, L. Ø. Pedersen ${ }^{2}$, J. Glamann ${ }^{2}$ \\ ${ }^{1}$ Department of Fish Diseases, Royal Veterinary and Agricultural University, 13 Bülowsvej, DK-1870 Frederiksberg C, \\ Denmark \\ ${ }^{2}$ Institute of Experimental Immunology, University of Copenhagen, 71 Nørre Allé, DK-2100 Ø, Copenhagen, Denmark
}

\begin{abstract}
A humoral immune response of European eel Anguilla anguilla to a major antigen in the swimbladder nematode Anguillicola crassus was demonstrated by immuno-blotting. Proteins from the nematode were separated using SDS-PAGE (sodium-dodecyl-sulfate polyacrylamide-gel electrophoresis) under reducing conditions and electroblotted onto nitrocellulose membranes, which were incubated in diluted serum from either infected or non-infected eels. Secondary and tertiary antibodies were rabbit anti-eel Ig serum and peroxidase-conjugated swine anti-rabbit Ig antibodies, respectively. Infected eels showed a specific antibody response towards a $43 \mathrm{kDa}$ parasite antigen. The immunoblotting technique seems to provide a serodiagnostic research tool for detecting $A$. crassus infection in the European eel.
\end{abstract}

\section{INTRODUCTION}

The swimbladder nematode Anguillicola crassus has been widely distributed in populations of both the Japanese eel (Anguilla japonica) and the European eel (A. anguilla) in Japan for many years (Egusa 1979), and over the last decade has spread within Europe in natural and cultured populations of $A$. anguilla (De Charleroy et al. 1990, Køie 1991). The endoparasite, whose life cycle includes a tissue migration phase, has the capacity to elicit a host immune response. The present paper reports on the humoral immune reaction of the European eel to this nematode. By using electrophoresis of parasite preparations and immunoblotting with host serum, we demonstrated the production of specific antibodies in naturally infected eels in response to a major immunogenic protein from Anguillicola crassus.

\section{MATERIALS AND METHODS}

Adult specimens of Anguillicola crassus were removed from the swimbladder of naturally infected European eels and sonicated in a sonifier B-12, Bran- son sonic power (Danbury, Connecticut, USA), at $50 \mathrm{~W}$ for $1 \mathrm{~min}$. SDS-PAGE (10\% polyacrylamide) was performed on the parasite suspension $(20 \mu \mathrm{g}$ protein lane $\left.{ }^{-1}\right)$ under reducing conditions according to Laemmli (1970). The separated proteins were electroblotted onto a nitrocellulose membrane $(0.45 \mu \mathrm{m})$ in a semidry blot apparatus (Kem-En-Tec, Copenhagen) (0.4 $\mathrm{mA} \mathrm{cm}{ }^{-2}$ for $2 \mathrm{~h}$ ) following the manufacturer's recommendations. Prior to incubation with dilutions of serum from infected and non-infected eels, the nitrocellulose membrane was incubated in blocking buffer ( $1 \%$ instant non-fat dry milk in phosphate-buffered saline, PBS) for $1 \mathrm{~h}$. Blood, collected by caudal vein puncture from 6 infected and 5 non-infected specimens of Anguilla anguilla, was allowed to clot for $1 \mathrm{~h}$, whereupon serum was recovered and frozen at $-20^{\circ} \mathrm{C}$ until use.

The nitrocellulose membrane with the fractionated parasite proteins was cut into strips and incubated in serum from individual eels $(6$ infected and 5 noninfected eels, diluted 1:50 in blocking buffer) or blocking buffer alone (control) for $8 \mathrm{~h}$ at $4{ }^{\circ} \mathrm{C}$. Detection of bound eel immunoglobulin was performed with 2 additional incubations, first with a rabbit anti-eel Ig serum (diluted 1:1000 in blocking buffer) (K. Buchmann, L. Ø. 
Pedersen \& J. Glamann unpubl.) and second with peroxidase-conjugated swine anti-rabbit Ig antibodies (diluted 1:2000) (P 217, DAKO-immunoglobulins A/S, Denmark). These incubations were performed for $1 \mathrm{~h}$ at room temperature. Following each incubation the nitrocellulose strips were washed 4 times for 15 min with PBS containing $0.05 \%$ Tween 80 . The strips were incubated in $80 \mathrm{mg}$ dioctyl-sulfo-succinate and $24 \mathrm{mg}$ tetramethyl benzidine in $10 \mathrm{ml} 96 \%$ ethanol, $30 \mathrm{ml}$ citrate phosphate buffer ( $\mathrm{pH}$ 5) and $20 \mu \mathrm{l} 30 \%$ hydrogen peroxide, for colour development on immuno-reactive bands.

\section{RESULTS}

SDS-PAGE of the sonicated parasite suspension yielded at least 15 distinct protein bands, with molecular weight (MW) ranging from $14 \mathrm{kDa}$ to more than 94 $\mathrm{kDa}$ (Fig. 1). The 6 sera from infected eels recognized

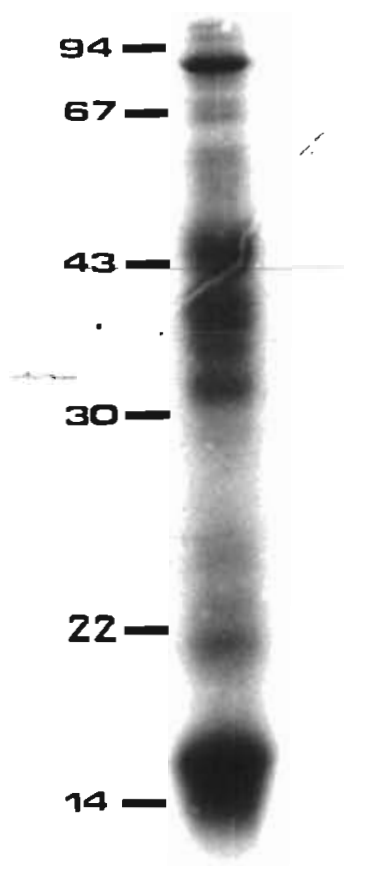

Fig. 1. Anguillicola crassus. SDS-PAGE (10\% polyacrylamide) of nematode sonicate run under reducing conditions and stained with Coomassie Blue. Molecular-weight markers are indicated in $\mathrm{kDa}$

specifically at least one of these protein bands, with an MW of ca $43 \mathrm{kDa}$. In addition, 2 infected eels (Nos. 1 and 2) reacted to 2 proteins of ca $67 \mathrm{kDa}$. Sera from non-infected eels did not show a reaction to either of these proteins. However, some of both the infected and non-infected eels reacted to 2 proteins with an MW of 60 and $94 \mathrm{kDa}$, but no reaction was seen in the control strip incubated in secondary and tertiary antibodies only (Fig. 2).

\section{DISCUSSION}

This study clearly demonstrates that the European eel is capable of effecting a humoral immune response to an antigen from Anguillicola crassus. Similar humoral immune responses of humans to hookworm antigens (Pritchard et al. 1990) and of calves to Ostertagia antigens (Canals \& Gasbarre 1990) have been reported. Lobos \& Weiss (1986) found that a number of antigens in the filarial nematode Onchocerca volvulus cross-reacted with serum from humans infected with other parasite species. However, a number of lowmolecular-weight antigens (20 to $43 \mathrm{kDa}$ ) in $O$. volvulus were found to be non-cross-reacting and more specific, reacting only with serum from onchocerciasis patients. Similarly, we found that serum from some non-infected eels reacted to a few high-molecularweight antigens from $A$. crassus, whereas only infected eels reacted to the low-molecular-weight antigen (43 kDa).

The immunoblot method provides a serodiagnostic tool which can be used for research purposes to detect Anguillicola infections in eel. Due to the relatively high costs of the technique, its usefulness for diagnosis in commercial eel farming is doubtful. However, based on the production of a recombinant non-cross-reacting antigen, a faster and more sensitive serodiagnostic method could be elaborated, corresponding to the work of Lobos et al. (1991) on Onchocerca volvulus infections in humans. A number of studies have been conducted on defence mechanisms of fish to helminths (Evans \& Gratzek 1989), and an attempt to serodiagnose trematode infections in Anguilla australis has been reported (McArthur \& Sengupta 1982). However. studies on the isolation and characterization of antigens in fish parasites are sparse. The exact nature of Anguillicola antigens should be the subject for future research. Also, a possible protective effect, if any, of the host's humoral immune response to $A$. crassus must be clarified, as we have no indication in the present work that the eel antibody response to this nematode performs such a function.

Acknowledgements. This work was supported by a grant from the Danish Agricultural and Veternary Research Council (K.B.), the Carlsberg Foundation (J.G.) and the Fish Biology Research Centre in Denmark (L.Ø.P.). S. Mellergaard, Danısh Institute for Fisheries and Marne Research, kindly provided some of the serum samples. 
Fig. 2. Anguilla anguilla and Anguillicola crassus. Immuno-blot showing reaction of serum from infected eels (Lanes 1 to 6) to major parasitic antigens separated with SDS-PAGE as in Fig. 1, and reaction of serum from non-infected eels (Lanes 7 to 11). Lane 12 (control) was only incubated in secondary and tertiary antibody Molecular-weight markers are indicated in $\mathrm{kDa}$

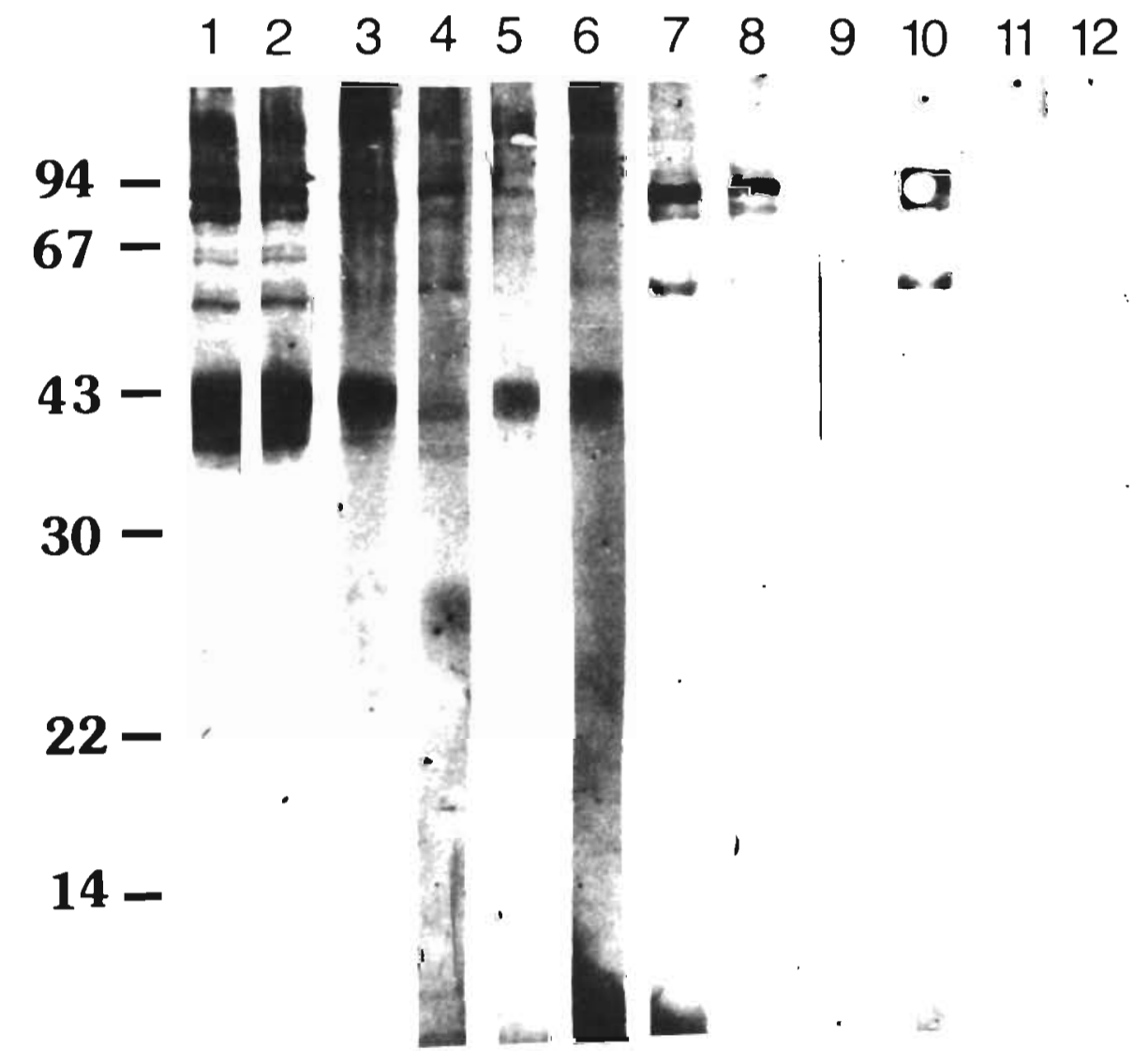

Laemmli, U. K. (1970). Cleavage of structural proteins during the assembly of the head of bacteriophage T4. Nature, Lond. 227: 680-685

Lobos, E., Weiss, N. (1986). Identification of non-cross-reacting antigens of Onchocerca volvulus with lymphatic filariasis serum pools. Parasitology 93: 389-399

Lobos, E., Weiss, N., Karam, M., Taylor, H. R., Ottesen, E. A., Nutman, T B. (1991). An immunogenic Onchocerca volvulus antigen: a specific and early marker of infection. Science 25: 1603-1605

McArthur, C. P., Sengupta, S. (1982). A rapid micro-method for screening of eel sera for antibodies against the digenean Telogaster opisthorchis MacFarlane, 1945. J. Fish Dis. 5: $67-70$

Pritchard, D. I., McKean, P. G., Schad, G. A. (1990). An immunological and biochemical comparison of hookworm species. Parasitology Today 6: 154-156

Manuscript first received: July 20, 1991

Revised version accepted: September 17, 1991 